value of the self-diffusion coefficient of $\mathrm{Si}$, needed to arrange the arriving atoms on proper lattice sites. Linear extrapolation of this border line to higher temperatures yields an intersection point with the LCVD curve at about $1520 \mathrm{~K}$. This value is in good agreement with the temperature limit we find for single-crystal growth of rods. The orientation of the rod axis was found to be close to either $\langle 100\rangle$ or $\langle 110\rangle$ crystallographic directions.

\section{Conclusion}

Laser induced deposition from the gas phase allows single-step production of material patterns with lateral dimensions from $0.5 \mu \mathrm{m}$ to several $\mathrm{mm}$. Typical deposition rates in laser pyrolysis are 10 to 100 $\mu \mathrm{m} / \mathrm{s}$ compared to 10 to some $100 \AA / \mathrm{s}$ in laser photolysis. The scanning velocities possible in laser pyrolysis reach at least up to about $500 \mu \mathrm{m} / \mathrm{s}$ for strongly adherent films. Laser pyrolysis at visible wavelengths combines high deposition rates and small lateral dimensions of deposits with standard laser techniques, simple optics and adjustment. Disadvantages of laser pyrolysis - compared to photolysis - are the stronger influence of the physical and chemical properties of the substrate and its surface quality and the higher local temperatures.

\section{BIBLIOGRAPHY}

For a description of standard chemical vapour deposition techniques see e.g.: Bloem J. and Giling L.J. in: Current Topics in Materials Science, ed. E. Kaldis (North-Holland, New York) 1978, Vol. 1, p. 147-342.

For more details on pyrolytic laser induced chemical vapour deposition see e.g. Bäuerle D. in: Laser Diagnostics and Photochemical Processing for Semiconductor Devices, eds. R.M. Osgood et al. (North Holland, New York) 1983; and Kräuter W. et al., Appl. Phys. A. 31 (1983) 13 and references therein.

Photolytic laser induced deposition is reviewed by Ehrlich D.J. et al., J. Vac. Sci. Technol. 21 (1982) 23.

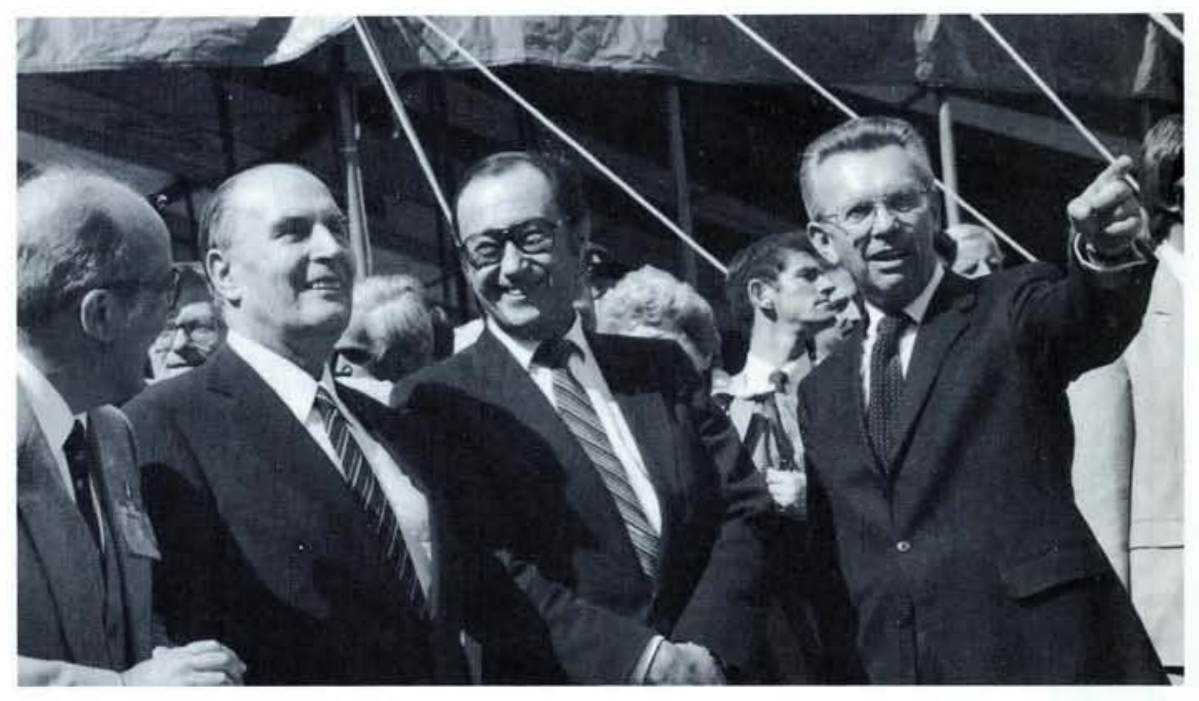

Underlining the international character of CERN, both organisational and physical, the start of construction of LEP - the 130-130 GeV electron-positron storage rings - was formally inaugurated by the Presidents of both France and Switzerland on 13 September. In the photograph taken at the ground-breaking ceremony are to the left of Francois Mitterand of France, Emilio Picasso, Director of the LEP Project and to the right of Pierre Aubert of Switzerland, Herwig Schopper, the Director-General of CERN. The $27 \mathrm{~km}$ circumference of LEP will lie 3/4 in France and 1/4 in Switzerland.

\title{
UNESCO Coupons
}

For the purchase of publications, films and material intended for educational, scientific or cultural purposes, buyers in some 54 countries throughout the world can make use of UNESCO Coupons. These are bought by governments in national currency from the United Nations at their official rate of exchange and are made available in the home country, sometimes with a surcharge (of $5 \%$ maximum). The coupons are redeemed by the supplier through the UNESCO Coupons Office which exacts a $3-5 \%$ handling charge that the supplier is expected to absorb. Most publishers are prepared to accept UNESCO coupons for subscription payments, as well as most equipment suppliers who are familiar with the scheme, but there is no obligation to do so.

Distributing offices in the countries covered by the EPS are as follows:
Austria:

Bulgaria :

France:

Poland:

Romania :

Spain:

UK:

Yugoslavia:

Hauptverband des Österreichischen Buchhandels Grünangergasse 4, 1010 Vienna 1

POB 386 , Sofia

CNRS, 23 rue du Maroc, 75940 Paris 19

Palac Kultury i Nauki, Warsaw

POB 71268, Bucharest

Instituto Nacional del Libro Español, Calle Santiago Rusiñol 8 , Madrid 3

Lloyds Bank International POB 241, London SW1Y 5HP

Institutes in other countries may make direct application for coupons to the UNESCO Coupons Office in Paris and this will be examined in the light of UN expenditure in the country concerned. Purchase of coupons in hard currency presents no problems.
EPS Divisions, Sections and Group

Astronomy and Astrophysics Division Solar Physics Section

Atomic and Molecular Physics Division

Atomic Spectroscopy Section

Chemical Physics

Electronic and Atomic Collisions

Molecular Physics

Computational Physics Group

Computational Physics Grou

Condensed Matter Division
Low Temperature Physics Section

Macromolecular Physics

Magnetism

Metal Physics

Semiconductors and Insulators

Surfaces and Interfaces

High Energy \& Particle Physics Division

Nuclear Physics Division

Nuclear Physics
Optics Division

Plasma Physics Division

Quantum Electronics Division
Europhysics News is the official journal of the European Physical Society which comprises 29 National Societies, Academies and Groups, over 3000 Individual Members and 68 Associate Members. Governing bodies of EPS are the General Meeting, Council and an elected Executive Committee responsible for detailed policy. EPS promotes the collaboration of physicists throughout Europe, organising and harmonising conferences, and promotes international exchanges in physics including participation in research and teaching activities abroad and attendance at schools. EPS publishes in addition to EN, Europhysics Conference Abstracts, E. Ed. News and, in collaboration with The Institute of Physics (UK), the European Journal of Physics. Individual Members receive EN free of charge (price to institutions: Sw.Fr. 82.-/a), rebates on the price of many publications and on conference fees. Annual fee for Individual Members from one of the EPS member societies for 1983 is: Sw.Fr. 40.-; independent members: SW.Fr. 120.-; APS members: Sw.Fr. 50. $-=\$ 25 .-$
Editor: E.N. Shaw

Meetings Compilation: W.S. Newman

Editorial Board:

K. Appert, A. Baratoff, B. Jacrot.

G.R. Macleod, A. Maeder, J. Muller

Editorial and Advertising Office at the EPS Secretariat.

Address: EUROPEAN PHYSICAL SOCIETY P.O. Box 69. CH-1213 Petit-Lancy 2

Switzerland

Telephone: Geneva (22) 931130

Telex: $\mathbf{4 2 3} \mathbf{4 5 5}$ dema ch

Cables: europhys genève

Printed by: Pfirter frères SA $\mathrm{CH}-1213$ Petit-Lancy/Switzerland 